\title{
Problems and Countermeasures in the Teaching Mode of the Modern Distance Education
}

\author{
He Ping Qiu Jing \\ Kunming University \&Department of Physical Science and \\ Technology \\ Kunming, China, 650214 \\ heping0871@qq.com
}

\begin{abstract}
Modern distance education is new educational form by making use of the modern information technique means, whose teaching mode is gradually forming.This text makes analysis to the existing teaching mode , and puting forward certain improvement measures and suggestions aiming at a series of existent problems, in order to push the reform and development of modern distance teaching mode.
\end{abstract}

Keywords-the modern distance education;Teaching mode;Problem;Suggestion

\section{INTRODUCTION}

Since the end of 20th century, mankind society gradually has got into an information-based society, but along with modern information technical development, producing a kind of new education form-modern distance education. So-called diatance education is that education organization carries out of outstrip the traditional campus timespace limits of education movable form with the help of a medium technique and various education resources.It with the modern diatance educational means for lord, comprehensive teaching face-to-face, correspondence, self-educated etc. teaching forms, adopt multimedia means to contact teachers and the students and load a courese contents.

Compared with traditional education diatance education can well develop modern information technical advantage, can carry out the combining of teaching methods effectively. Taking learner independence study as center broke various timespaces tie of traditional teaching methods in the school, which is a study realms of newness. And the change of distance education studied object and ways also cause the change of teaching mode.Because of the complicated diversification of teaching mode, come to a decision setting up of teaching mode is an engineering with complicated system, therefore, the standpoint used system carries on whole consideration and system design in the middle of the teaching mode formation process to each related part with carry out teaching mode of excellent turn and then become an important topic that we face at present.

\section{THE CONCEPT AND STRUCTURE OF THE DISTANCE EDUCATION TEACHING MODE}

\author{
A. The Concept of Teaching Mode \\ Teaching mode one phrase was put forward by
}

\author{
Shao Feng Ge \\ He nan HuaiYang teachers' further education school \\ Huaiyang, China, 466700 \\ 1515998421@qq.com
}

American scholar's Joyce and the Wei Er , and published in 1972 of 《teaching mode 》 made the introduction of system in one book.They think that teaching mode is model or plan of constitute course and lessons, choice teaching material and hint teacher's activity. Teaching technique expert think:The teaching mode means under support that certain education thought, teaching theories and study theories guides under, in a certain teaching environment and the resources, teach and learn each main factor( teacher, student, contents and media) in the activity of relation and activity progress structure form of stability.It is the comprehensive system of the teaching theories, teaching target and teaching strategy, teaching organized form and teaching environment and evaluation method.

\section{B. The Structure of the Teaching Mode}

Although the definition disunity of people's concept to the teaching mode, as to it's the structural understanding is unanimously basic.. Any teaching mode all the indispensability teaching thought( or teaching theories), teaching target and study support the service environment, "person machine role relation", teaching strategy and teaching evaluate etc. main factor.The teaching thought is the foundation that the teaching mode relies on for forming, the different teaching thought will form different teaching mode.The teaching target is the expectation teaching that the teaching mode pursues effect, is the direction of longrange education teaching mode whole movement.Studying support service environment is the foundation condition that the modern long range education teaching mode relies on for circulating."Person machine role relation" is the important factor of modern distance education teaching mode, teachers and the students and different of the different relation creation of of multi-media resources come about different functions, constituted the teaching mode of each special feature thus.The teaching strategy is a modern long range education the opposite stability had by teaching mode to circulate structural of outside performance.And different teaching mode, its teaching contains different target and get the teaching of to evaluate also dissimilarity. 


\section{TEACHING MODE OF THE MODERN DISTANCE EDUCATION}

\section{A. Correspondence Teaching Mode}

This kind of teaching mode mainly combines together through writing teaching material and postal delivery system, the teacher passes to carry on correcting and review to note to the student's homework to help student's study.The student can freely choose to study time and location, basic be free from time to limit.But blemish is hand over a function with each other of the degree isn't enough and not in time, is as higher as self-educated ability's requesting to the knowledge of already having of the student, but the only one standard of evaluation then the student's examination result.This kind of teaching mode at our country common universities and colleges long -range teaching practice in universal existence, England in earlier period's opening university is also the typical model of this kind of mode.

\section{B. Comprehensive Multimedia Teachings Mode}

Comprehensive multimedia teachings mode (include a broadcasting, television, recording, record image and writing teaching material etc.) to carry on teaching, the teachers and the students strengthened double comprehension. The utilization of various media changed originally single writing teaching material, technique expert and educational expert and academics the teacher constitute of the media created a group to replace a traditional teacher.In this kind of mode, the establishment of teaching material and progress , the creation of media morely set out from the student and from the angle of study and start emphasizing the development of study ability of the students.

\section{The Network Study Mode}

Network's studying mode is a gradually formative system under the network environment of with stable learning process structure and study movable procedure, adopting the way of independent and harmonious study mainly. Comparatively traditional study, the network study has the following three characters:One, it shares an abundant network study resources; Two , with the independent and cooperative study for main form; Three, It broke the timespace restriction of traditional study.In this kind of mode, face numerous information resourceses of Internets, the student's study ability becomes a key, As the teacher has not the main source of knowledge information any more, The importance of the teacher have gradually been weakened in the teaching mode, the student becomes main part more.Teachers become assistances in the school.
TABLE I THE TEACHING PROCEDURE OF CORRESPONDENCE TEACHING MODE

\begin{tabular}{|c|l|l|}
\hline Sequence & \multicolumn{1}{|c|}{ Teaching stage } & \multicolumn{1}{c|}{ Main task } \\
\hline One & $\begin{array}{l}\text { Teachers' } \\
\text { preparation } \\
\text { Work out suitable study } \\
\text { software for students, } \\
\text { provides study contents } \\
\text { and time to make } \\
\text { reference to etc. }\end{array}$ \\
\hline Two & $\begin{array}{l}\text { Students'preparati } \\
\text { on }\end{array}$ & $\begin{array}{l}\text { Establish study target, } \\
\text { plans...etc }\end{array}$ \\
\hline Three & $\begin{array}{l}\text { Student's } \\
\text { separation type }\end{array}$ & $\begin{array}{l}\text { Press to request oneself } \\
\text { that the sequence studies } \\
\text { the school provides of } \\
\text { study material, complete a } \\
\text { homework etc. }\end{array}$ \\
\hline Four & $\begin{array}{l}\text { The teacher } \\
\text { periodically } \\
\text { supports a help } \\
\text { service }\end{array}$ & $\begin{array}{l}\text { Correct student's } \\
\text { homework, the short-term } \\
\text { face -to-face teaching }\end{array}$ \\
\hline Five & $\begin{array}{l}\text { Consolidate each } \\
\text { other }\end{array}$ & $\begin{array}{l}\text { The teachers and the } \\
\text { students pass mail } \\
\text { telephone etc. to carry on } \\
\text { interaction and answer } \\
\text { difficulty }\end{array}$ \\
\hline
\end{tabular}

\section{THE EXISTING PROBLEM IN THE MODERN} DISTANCE EDUCATION TEACHING MODE

\section{A. The Teaching Quality can not Get Basic Assurance}

Because distance education is a kind of new education form of creation, along with information technical development, its development history is briefer, each college school isn't explicit to the fixed position of oneself college of network, the condition of study center establishing in the outside of school is also not even, it fosters target and quality standard and quality control system also each not same, which causes distance education teaching quality cann not get basic assurance.

\section{B. Teaching Process Supervision Disadvantageous}

Currently, most concern of the greatly parts of distance education is curricular end examination, but inattentive to the quality of learning process.To student, ending the examination is surely important, but the teaching process cans not neglect, either.The distance learner differs from a common high school student, The ability doesnot adopt traditional educational method in controling quality .We should pay attention to learning process quality, and put together course terminative examination to the process quality.

\section{Network Study Efficiency Low}

Along with the universality of the calculator network , the conditions that the students generally get to the Internet can get assurance, greatly parts of students on the Internet are usually "a heart much uses" in this time, they watch network course as do other matters, They don't listen to the tuition of network course basicly, they finally ended a 
course superficially, they could not learn any knowledge.And many students take part in of long- range educational background education just for canning easily get hold of diploma .They lack study motive and can't study hard and systematically actively on their own initiative full exploitating rich study resources study .They concern not learning process but finally examine result.

\section{Using of Study Resource Rate Low}

Although study resources is abundant, the form is also varied, learners do not interested in these resources in the distance teaching, with as for many resourceses are all wasted for nothing and lowered the utilization rate of the study resources.

\section{CARRY OUT THE COUNTERMEASURES THAT MODERN DISTANCE EDUCATION TEACHING MODE REFORMS}

\section{A. Set up Quality Management Idea, Carry out Practical Effective Quality Supervise and Control Measure:}

- Strengthen the management of the teaching target:Developing the course of network study,we should have explicit study target . Course development and college whole strategic target unify mutually. Periodically approve officially teaching material with ensure that the teaching material can always meet course target and standard request.The relation that studies target, student's homework and student to measure to review should has coherent and forms united frame structure.

- Strengthen teaching process management: Perfect on-line operation system, the teacher passes a homework to check student's acquired degree study contents degree, in time feedback teaching effect, and adjust teaching strategy in time.Develop evaluation of encourage function, making student's corpus get respect, making them morely experience study success of joy.For encouraging students value learning process, we can investigate formation result to raise the proportion of the formation result.

\section{B. Build up Agile Efficient Distance Teaching orGanization}

Distance education is a kind of new education form. It isn'tcommendable we copy traditional education theory mode and fulfillment experience t.Aim at to open agile long- range education, need to be built up agile efficientl long- range teaching organization. According to the student's different establishments, such as profession, course, knowledge foundation and interest...etc. has already developed a teaching work pertinently.

\section{Raise the Study Efficiency on-line}

Carrying on preschool education and training, lets them intentionly take part in long -range education understand characteristics and basic study procedure, controling calculator operation technical ability and related network knowledge, then carry on the examination that corresponds a contents.Examination process guards strictly, don't low request. Only qualified result people can get into the college of network.We should enhance students' learning motive to make them establish study view of science and personal study plan.In the learning process, we carry on guiding in many ways ,such as aiming at the student's interest and fondness , developing learner's study strategy and carrying on a whole distance councilor. The study environment of guidance should be established for difficult problems, guiding and encouraging students study with each other through a related exchanges tool realization.The learner oneself has to consciously adjust his/her own study strategy and cognition strategy, foster independent study ability , raise ego supervisory and manageable ability, learn to program his/her own study and raise own study efficiency.

\section{REFERENCES}

[1] Ding xin, "The comparison and individual case analysis of the distance education teaching mode-setting up of"teaching mode seven dimension analysis frame" and apply," Open education research,2009

[2] Yang Qingzhen, "The American long -range education and its apocalypse, ” The modern long-distance education.,2006

[3] Chen Xu Jian, "Explorations and practice in the modern distance education of teaching mode,"Guangxi broadcasts telivision college journal,2004

[4] Ji He, "Choosing and introspects of the distance education of teaching mode,”Jiangsu broadcasts television college journal,2002

[5] Zhan Biqing,Lin Chao Wen,Jiang Jian sheng,Lin Ruohong,Huang Xiu Dan,Cai Wen rong, "The study of the modern distance education teaching mode,”The Chinese distance education,2002

[6] Wang Jia, "The study of modern distance education of teaching mode,”Chinese Gao Jiao's research,2001

[7] Zheng Huling,Liu Jian ping, "Comparison research the distance education of teaching mode,"Guangxi broadcasts television college journal,2000

[8] Yu Shengquan, Zhao Xing Long, "The district of information ecosystem view information-based push forward,"The Chinese electric education, 2009

[9] LiJiahou, "High school student and teacher spirit activity in the creative educational information-based environment ,"The electric education research, 2002 